Jurnal Mahasiswa BK An-Nur : Berbeda, Bermakna, Mulia

Volume 7 Nomor 2 Tahun 2021

Tersedia Online: https://ojs.uniska-bjm.ac.id/index.php/AN-NUR

p-ISSN. 2460-9722 | e-ISSN. 2622-8297

\title{
PENERAPAN PEMBELAJARAN JARAK JAUH SELAMA MASA PANDEMI COVID-19 PADA SISWA KELAS V SDN 2 SOKARAJA KULON
}

\author{
Ari Pratiwi ${ }^{1} \&$ Asih Ernawati ${ }^{2}$ \\ ${ }^{1,2}$ Universitas Muhammadiyah Purwokerto, Banyumas, Indonesia \\ E-mail: ${ }^{1}$ apratiwi181@gmail.com, +6282235064947
}

\begin{abstract}
ABSTRAK
Penelitian ini merupakan penelitian kualitatif yang bertujuan untuk (1) mengetahui pelaksanaan pembelajaran jarak jauh dimasa pandemi covid-19, (2) mengetahui tantangan yang dihadapi sekolah dan guru saelama pelaksanaan pembelajaran jarak jauh, (3) mengetahui tantangan yang dihadapi orang tua dan siswa selama pelaksanaan pembelajaran jarak jauh. Pengambilan data penelitian dilaksanakan di SDN 2 Sokaraja Kulon pada bulan Februari 2021. Partisipan pada penelitian ini adalah kepala sekolah, guru, orang tua dan siswa kelas V. Teknik pengumpulan data menggunakan observasi, wawancara dan dokumentasi. Analisis data pada penelitian ini menggunakan model Miles dan Huberman. Peneliti menggunakan triangulasi teknik dan triangulasi sumber untuk mengukur keabsahan data. Berdasarkan analisis hasil penelitian ini menunjukan bahwa (1) pelaksanaan pembelajaran jarak jauh di SDN 2 Sokaraja Kulon menggunakan Whatsapps dan Google Meet sebagai sarana pembelajaran, (2) tantangan yang dihadapi oleh sekolah dan guru antara laian adalah kurangnya kesiapan guru, kesesuaian kurikulum dan kurangnya kemampuan dalam menggunakan teknologi, (3) tantangan yang dihadapi oleh orang tua dan siswa tidak lain adalah sulitnya membagi waktu bagi orang tua untuk mendampingi anak dan melakukan kegiatan lain, selain itu siswa juga kesulitan dalam memahami materi pembelajaran tertentu.
\end{abstract}

Kata Kunci: Pembelajaran Jarak Jauh, Tantangan

\begin{abstract}
(10 pt)
This qualitative research aims to (1) know the implementation of distance learning during the Covid-19 pandemic, (2) know the challenges faced by schools and teachers during the implementation of distance learning, (3) know the challenges faced by parents and students during implementation of distance learning. Data was collected at SDN 2 Sokaraja Kulon in February 2021 through observation, interview, and documentation. Participants in this study were the principal, teachers, parents and fifth grade students. The data analysis in this study utilized the Miles and Huberman model were used as a tool to analyze the data, while two types of triangulation were used to measure the validity of the data. The study showed that (1) SDN 2 Sokaraja Kulon implemented its distance learning through Whatsapps and Google Meet as learning tools, (2) the challenges faced by schools and teachers among others were the lack of teacher readiness, curriculum suitability and lack of technological ability (3) the challenges faced by parents and students were the difficulty of dividing time for parents to accompany children and carry out other activities, besides that students also had difficulty understanding certain learning materials.
\end{abstract}

Keywords: Distance Learning, challenges

Dipublikasikan Oleh :

UPT Publikasi dan Pengelolaan Jurnal

Universitas Islam Kalimantan Muhammad Arsyad Al-Banjari Banjarmasin 


\section{PENDAHULUAN}

Pendidikan menjadi wadah untuk mengembangkan potensi seseorang dalam hal ini khususnya seorang siswa. Setiap siswa perlu mendapatkan dukungan dari orang tua dan guru agar dapat mengembangkan potensinya untuk berkontribusi di masyarakat dikemudian hari. Daya dukung ini mendapat tantangan yang serius sehubungan dengan adanya pandemi Corona Virus Disease 2019 (Covid 19). Akibat yang ditimbulkannya merebak ke dalam hampir seluruh kegiatan masyarakat termasuk bidang pendidikan. Pada skala nasional dan bahkan global, proses pembelajaran di sekolah terhenti dengan tibatiba dan segera beralih menjadi sistem pembelajaran jarak jauh guna mengantisipasi gangguan ancaman dari pandemi Covid-19 ini. Pengalihan ini tentunya memiliki dampak yang cukup serius terhadap efektifitas proses belajar dan mengajar.

Pengalihan dari pembelajaran tatap muka ke pembelajaran jarak jauh membuat pemerintah dan Kementrian Pendidikan dan Kebudayaan mengeluarkan Surat Edaran Menteri Pendidikan dan Kebudayan No. 4 Tahun 2020 tentang Pelaksanaan Kebijakan Pendidikan dalam Masa Darurat Covid 19. Proses belajar dari rumah merupakan hal yang baru bagi sebagian keluarga di Indonesia, itu merupakan kejutan besar khususnya bagi produktivitas orang tua yang biasanya sibuk dengan pekerjaannya di luar rumah. Belum lagi perbedaan wilayah yang menjadikan bertambahnya permasalahan terkait koneksi ataupun perangkat yang akan digunakan dalam proses pembelajaran.

Berdasarkan survei yang dilakukan oleh Kementerian Pendidikan dan Kebudayaan Republik Indonesia adanya Pandemi Covid - 19 mengakibatkan pembelajaran interaktif yang dilaksanakan kurang dari $40 \%$ selebihnya hanya mengerjakan tugas sesuai dengan jadwal pelajaran. Guru dituntut untuk mampu melakukan pengajaran dengan daring, kemampuan guru dalam teknologi informasi sangat dibutuhkan. Guru dituntut untuk merombak kembali rencana pembelajaran dengan metode daring, metode pembelajaran juga harus efektif sehingga proses pengajaran berjalan efektif dan ilmu dapat tersampaikan. Guru dituntut untuk inovatif dalam menggunakan pembelajaran dengan model daring.

Pelaksanaan pembelajaran jarak jauh tidak hanya menjadi tantangan bagi sekolah dan guru melainkan menjadi tantangan tersendiri bagi siswa dan orang tua. Di era pandemi covid-19 ini, tanggung jawab dan peran orang tua dalam pembelajaran anak sangat berpengaruh karena sebagian tugas dari guru sudah dilakukan oleh para orang tua. Penerapan pembelajaran jarak jauh membutuhkan peran penting dari orang tua untuk mendampingi siswa dalam proses belajar. Berdasarkan survai Whatsapps Group menjadi aplikasi dengan pengguna terbanyak selama proses pembelajaran jarak jauh karena aksesibilitasnya terutama di kalangan orang tua yang gagap teknologi.

Melalui wawancara guru menyampaikan ada banyak hambatan dalam proses pelaksanaan pembelajaran jarak jauh khususnya di kelas V. Guru kelas $\mathrm{V}$ menyampaikan hambatan yang terjadi tidak hanya dari tingkat kemampuan siswa yang berbeda selama pelaksanaan pembelajaran jarak jauh. Berdasarkan pemaparan di atas, peneliti tertarik melakukan penelitian di SDN 2 Sokaraja Kulon guna mengetahui proses pelaksanaan pembelajaran jarak jauh dan tantangan yang dihadapi oleh sekolah, guru, siswa dan orang tua selama pembelajaran jarak jauh.

\section{METODE}

Penelitian ini menggunakan kualitatif deskriptif. Penelitian kualitatif digunakan peneliti untuk menggali informasi lebih mendalam sehingga dapat memperoleh data yang lebih lengkap dan bermakna dari pratisipan. Peneliti menggali informasi menggunakan prosedur pengumpulan data sesuai dengan waktu yang sudah ditentukan. Penelitian dilaksanakan pada bulan Februari-Maret 2021 bertempat di SDN 02 Sokaraja Kulon tepatnya di kelas V. partisipan dalam penelitian ini adalah kepala sekolah, guru, orang tua dan siswa kelas V SD Negeri 02 Sokaraja Kulon. Siswa yang diijinkan untuk ikut serta dibatasi oleh guru seju lah 5 orang.

Teknik pengumpulan data yang digunakan dalam penelitian guna memperoleh data antara lain observasi, wawancara dan dokumentasi. Analisis data yang digunakan oleh peneliti adalah analisis data kualitatif. Penelitian ini menggunakan analisis data model Miles dan Huberman. Terdapat tiga tahap dalam analisis data yaitu reduksi data, penyajian data, dan penarikan simpulan dan verifikasi. Uji keabsahan data pada penelitian ini menggunakan triangulasi. Ada dua jenis trianulasi yang digunakan dalam penelitian ini yaitu triangulasi teknik dan triangulasi sumber.

\section{HASIL DAN PEMBAHASAN \\ Pelaksanaan Pembelajaran Jarak Jauh}

Pelaksanaan pembelajaran jarak jauh merupakan alternatif yang dipilih selama pembelajaran tatap muka diberhentikan karena adanya pandemi covid-19. Dampak ini tidak hanya dirasakan oleh negara Indonesia saja tetapi seluruh dunia.

Dipublikasikan Oleh : 


\section{Ari Pratiwi ${ }^{1} \&$ Asih Ernawati ${ }^{2}$ \\ Jurnal Mahasiswa BK An-Nur : Berbeda, Bermakna, Mulia \\ Volume 7 Nomor 2 Tahun 2021 \\ Tersedia Online: https://ojs.uniska-bjm.ac.id/index.php/AN-NUR \\ p-ISSN. 2460-9722 | e-ISSN. 2622-8297}

Pembelajaran jarak jauh seperti dijelaskan pada kajian teori merupakan pembelajaran dimana guru dan siswa tidak bertemu secara langsung. SDN 2 Sokaraja Kulon adalah salah satu sekolah yang menerapkan pembelajaran jarak jauh sejak awal pandemi Covid-19 pada maret 2020. Satu bulan pelaksanaan pembelajaran jarak jauh guru-guru diperbolehkan ke sekolah secara bergantian sesuai dengan jadwal sesuai dengan Surat Edaran Kepala Dinas Pendidikan Kabupaten Banyumas Nomor 422.4/2177/2020 tanggal 4 April 2020 tentang Penyesuaian/Evaluasi Sistem Kerja ASN dan Non ASN bagi Pengawas/Pemilik, Guru, Tutor, Pamong Belajar, Tenaga Kependidikan dan Waktu Belajar Peserta Didik dalam upaya pencegahan penyebaran Covid-19 di lingkungan Dinas Pendidikan. Guru menggunakan HP sebagai media untuk berkomunikasi dengan orang tua dan siswa. Guru menyampaikan materi pembelajaran secara online melalui pesan suara, video materi di youtube atau video buatan guru sendiri. Penggunaan aplikasi tertentu diperlukan untuk menunjang proses pembelajaran jarak jauh. SDN 2 Sokaraja Kulon sepakat menggunakan aplikasi Whatsapp dan Google Meet untuk pembelajaran jarak jauh. Hal ini memudahkan guru menjelaskan materi melalui pesan suara atau video kepada siswa. Pelaksanaan pembelajaran jarak jauh lebih dominan menggunakaibandingkan menggunakan Google Meet.

Selama pelaksanaan pembelajaran jarak jauh durasi pembelajaran relatif singkat yaitu di mulai Pukul 08.00 WIB sampai Pukul 11.00 WIB. Selain singkat waktu pelaksanaan juga lebih fleksibel. Hal ini untuk bertujuan agar mood anak tetap baik ketika pembelajaran. pembelajaran dimulai dengan memeriksa kehadiran siswa melalu Whatsapps grup. Setelah itu guru melanjutkan dengan memberikan materi melalui pesan suara dan video baik video dari youtube atau buatan guru sendiri. setelah guru menjelaskan dilanjutkan dengan pemberian tugas kepada siswa yang kemudian dikumpulkan ke sekolah satu minggu sekali. Tugas-tugas tersebut kemudian dikoreksi dan dinilai oleh guru dan dikembalikan kepada siswa diminggu selanjutnya sebagai apresiasi dan umpan balik yang diberikan guru kepada siswa. Penilaian selama pembelajaran jarak jauh dilakukan dengan menggunakan penilaian protofolio dan juga tes berbasis daring. Asesmen sikap diambil dari pengamatan guru ketika siswa ke sekolah untuk mengumpulkan tugas. Guru akan mengamati sikap sopan siswa dari caranya berkomunikasi dengan guru. Kedisiplinan siswa dari ketepatan siswa mengumpulkan tugas. Hal tersebut dianggap efektif oleh guru.

Kurikulum baru yang sesuai dengan pembelajaran jarak jauh juga diterapkan di SDN 2 Sokaraja Kulon. Selain itu sekolah juga memberikan fasilitas kepada siswa berupa buku tema dari tema 1-9 yang bisa dipinjam dan LKS dari tema 1-9 yang dapat dibeli oleh siswa sebagai pendamping belajar. Pemerintah juga memberikan fasilitas kepada siswa berupa kuota. Fasilitas uga diberikan kepada guru berupa pelatihan mengenai penggunaan media sealam pembelajaran jarak jauh. pelatihan tersebut diberikan sebanyak 3 kali oleh UPT Dinas Pendidikan yang dilaksanakan pada bulan Juni dan Agustus dengan masing-masing sekolah mengirim 4 orang guru sebagai perwakilan mengikuti Bimbingan dan Pelatihan.

\section{Tantangan Kepala Sekolah dan Guru}

Pelaksanaan pembelajaran jarak jauh merupakan hal baru bagi sekolah maupun guru. Hal tersebut tentu memberikan tantangan tersendiri bagi sekolah dan guru selama pelaksanaan pembelajaran jarak jauh. Berdasarkan hasil temuan dilapangan kepala sekolah dan guru menyadari bahwa kemampuan dalam menggunakan teknologi sangat diperlukan dalam pembelajaran jarak jauh. Hal tersebut menjadi tantangan yang mendasar bagi sekolah dan guru. Tantangan lain yang dihadapi oleh kepala sekolah dan guru adalah kesiapan pendidik, kurikulum yang sesuai, ketersediaan sumber belajar, serta dukungan media dan jaringan yang stabil sehingga komunikasi antar peserta didik dan pendidik dapat efektif. Kepala sekolah dan guru memberikan solusi guna menghadapi tantangan tersebut dengan memberikan fasilitas kepada siswa berupa buku pinjaman dan menyediakan LKS yang dapat dibeli oleh siswa sebagai pendamping selama pembelajaran jarak jauh. Solusi lain yang diberikan adalah memfasilitasi guru untuk mengikuti pelatihan pelaksanaan pembelajaran jarak jauh sehingga guru lebih siap dalam memberikan materi pembelajaran kepada siswa.

Tantangan yang kerap dihadapi oleh guru adalah keahlian dalam mendesain materi pembelajaran dengan menarik dan mudah dipahami oleh siswa. Pembelajaran yang menarik cukup sulit dilakukan apalagi dengan kondisi guru dan peserta didik terpisah karena pembelajaran jarak jauh. Guru juga kesulitan ketika memberikan nilai kepada siswa terutama nilai sikap. Guru mengatasai masalah tersebut dengan membuat video pembelajaran sendiri pada mata

Dipublikasikan Oleh :

UPT Publikasi dan Pengelolaan Jurnal

Universitas Islam Kalimantan Muhammad Arsyad Al-Banjari Banjarmasin 
pelajaran yang sulit dipahami oleh siswa yaitu Matematika. Guru juga memanfaatkan video pembelajaran yang sudah tersedia di Youtube untuk membantu siswa memahami materi pembelajaran atau menyampaikan melalui pesan suara dan melakuakan tatap muka virtual. Guru mengambil nilai dari tugastugas yang diberikan oleh siswa. Selain itu nilai juga diambil dari hasil tes seperti ulangan harian, Penililaian Tengah Semester(PTS) dan Penilaian Akhir Semester(PAS).

\section{Tantangan Orang Tua dan Siswa}

Tantangan pembelajaran jarak jauh tidak hanya dirasakan oleh kepala sekolah dan guru tapi juga dirasakan oleh orang tua dan siswa. Orang tua diberi tugas tambahan untuk mendampingi anak-anaknya selama pembelajaran jarak jauh. Orang tua harus mampu membagi waktu antara mengurus rumah, bekerja dan mendampingi anak bersekolah. Hal tersebut tentu menambah tingkat kestresan ibu sebagai ibu rumah tangga dan penamping anak belajar di rumah. Kurang mahirnya orang tua dalam menggunakan teknologi juga menjadi tantangan bagi orang tua agar dapat mengikuti pembelajaran jarak jauh ini. Tempat tinggal yang tidak mendukung jaringan internet juga menjadi tantangan bagi orang tua sehingga tidak sedikit orang tua yang mencari cara untuk memperoleh jaringan yang kuat seperti memasang Wi-fi atau menumpang ke rumah tetangga yang sudah memiliki Wi-fi. Kepemilikan HP yang bergantian antara orang tua dan anak juga menjadi tantangan bagi orang tua dan siswa. Kesulitan memahami materi juga dihadapi oleh siswa selama pembelajaran.

Pembelajaran yang diberikan dengan cara memberikan materi dan penjelasan tanpa adanya diskusi juga menjadi faktor mengapa siswa sulit memahami materi. Pembelajaran jarak jauh membuat siswa berpikir bahwa mereka sedang libur sehingga malas untuk belajar ditambah lagi dengan banyaknya tugas yang diberikan membuat orang tua mengeluh. Berdasarkan hasil temuan dilapangan sebagian besar orang tua tidak setuju pembelajaran jarak jauh karena menyulitkan anak dan membebani orang tua apalagi ketika orang tua bekerja.

\section{PENUTUP}

Berdasarkan hasil penelitian dan pembahasan dapat disimpulkan bahwa pelaksanaan pembelajaran jarak jauh sudah berjalan dengan baik. Sekolah mampu beradaptasi dengan menerapkan kurikulum baru yang sesuai. Guru juga mampu melaksanakan pembelajaran dengan baik melalui Whatsapp Grup dan Google Meet. Guru memberikan materi melalui pesan suara, video dari youtube dan video buatan guru sendiri. Sekolah dan pemerintah juga memberikan fasilitas bagi siswa dan guru selama pelaksanaan pembelajaran jarak jauh. Pelaksanaan jarak jauh juga memberikan tantangan bagi sekolah dan guru. Kurangnya kemampuan menggunakan teknologi, kesiapan pendidik kurikulum yang sesuai, ketersediaan sumber belajar, serta dukungan media dan jaringan yang stabil. Serta tantangan bagi guru agar mampu memberikan pembelajaran yang menarik dan penilaian yang tepat selama pembelajaran jarak jauh. Tidak hanya sekolah dan guru, orang tua dan siswa juga merasakan tantangan terkait pelaksanaan pembelajaran jarak jauh. Orang tua dituntut untuk mampu membagi waktu antara urusan lain dengan mendampingi anak belajar. Selain itu orang tua juga mendapat tantangan karena kemampuan berteknologi yang kurang serta kondisi tempat tinggal yang tidak mendukung jaringan yang stabil. Pembelajaran yang hanya memberikan materi dengan sedikit penjelasan juga membuat siswa kesulitan dalam memahami materi. Pembelajaran yang fleksibel juga meningkatkan rasa malas belajar pada siswa.

Berdasarkan hasil temuan dan pembahasan yang telah diuraikan maka dapat diajukan empat saran yaitu, 1) Pelaksanaan pembelajaran jarak jauh jangan hanya dilakukan komunikasi satu arah tetapi dua arah diselipkan proses tanya jawab atau diskusi didalam pembelajaran sehingga ada pembelajaran yang interaktif sehingga siswa tidak merasa malah untuk mengikuti pembelajaran. 2) Sosialisasikan terkait pembelajaran jarak jauh dengan baik dan jelas kepada orang tua sehingga orang tua menyiapkan diri dalam mendampingi anaknya belajar di rumah. 3)Pelatihan terkait pembelajaran jarak jauh perlu dilaksanakan secara bertahap dan berulang sehingga guru tidak monoton dalam menyampaikan materi terhadap siswa. 4) Evaluasi pembelajaran jarak jauh lebih ditekankan lagi agar tercipta pembelajaran yang efektif.

\section{REFERENSI}

Amini, Clifford M. dan Oluyide, Oluwaseun P. (2020). Analysis of ICT Competencies Among Distance Learning Students in selected Study Centres of the National Open University of Nigeria. Journal of Learning for Development (JLAD). 7(1). $78-89$.

Creswell, John W. (2013). Research Design Pendekatan Kualtatif, Kuantitatif, dan Mixed. Yogyakarta:Pustaka Belajar.

Dipublikasikan Oleh : 
Ari Pratiwi ${ }^{1} \&$ Asih Ernawati ${ }^{2}$

Jurnal Mahasiswa BK An-Nur : Berbeda, Bermakna, Mulia

Volume 7 Nomor 2 Tahun 2021

Tersedia Online: https://ojs.uniska-bjm.ac.id/index.php/AN-NUR

p-ISSN. 2460-9722 | e-ISSN. 2622-8297

Kemendikbud. (2020). Surat Edaran No.4 tentang Pelaksanaan Kebijakan Pendidikan Dalam Masa Darurat Penyebaran Corona Virus (COVID-19). Jakarta:Kemendikbud.

Kor, H., Aksoy, H., \& Erbay, H. (2014). Comparison of the Proficiency Level of the Course Materials (Animations, Videos, Simulations, E-books) Used in Distance Education. Procedia - Social and Behavioral Sciences, 1(1):854-860.

Prawiyogi, A. G. dkk. (2020). Efektifitas Pembelajaran Jarak Jauh Terhadap Pembelajaran Siswa Di Sdit Cendekia Purwakarta. Jurnal Pendidikan Dasar, 1(1):94-101.

Septantiningtyas, Niken. (2018). Pengaruh Pembelajaran Jarak Jauh Dengan Aplikasi Google Class Terhadap Hasil Belajar Mahasiswa.Jurnal Pendidikan Agama Islam. 2(2). 131-5.

Dipublikasikan Oleh :

UPT Publikasi dan Pengelolaan Jurnal

Universitas Islam Kalimantan Muhammad Arsyad Al-Banjari Banjarmasin 